\title{
Influences of the stream groundwater hydrology on nitrate concentration in unsaturated riparian area bounded by an intermittent Mediterranean stream
}

\author{
A. Butturini, ${ }^{1}$ S. Bernal, and E. Nin \\ Departament de Ecología, Universitat de Barcelona, Barcelona, Spain \\ C. Hellin and L. Rivero \\ Departament de Geoquímica Petrologia I Prospecció Geológica, Zona Universitaria de Pedralbes, Barcelona, Spain
}

S. Sabater ${ }^{2}$ and F. Sabater

Departament de Ecología, Universitat de Barcelona, Barcelona, Spain

Received 19 February 2002; revised 16 September 2002; accepted 5 March 2003; published 30 April 2003.

[1] Stream aquifer hydrology and nitrate removal were studied, over a period of 2 years, in an unsaturated riparian zone, bounded by an intermittent Mediterranean stream,

(Fuirosos, northeastern Spain). The riparian groundwater system is characterized by drastic hydrological changes and by mixing of stream water with hillslope groundwater. The hillslope groundwater flowed through a medium with low hydraulic conductivity $(9.6$ $\left.10^{-3}<\mathrm{k}_{\mathrm{s}}<0.1 \mathrm{~m} \mathrm{~d}^{-1}\right)$ and low specific discharges $\left(1.710^{-3}<\mathrm{q}_{h l l}<1510^{-3} \mathrm{~m} \mathrm{~d}^{-1}\right)$. In contrast, stream water infiltrated through the near stream porous medium with relatively high hydraulic conductivity $\left(4.8<\mathrm{k}_{\mathrm{s}}<19 \mathrm{~m} \mathrm{~d}^{-1}\right)$ and variable specific discharges (i.e., $0.03<\mathrm{q}_{s t}<1.5 \mathrm{~m} \mathrm{~d}^{-1}$ ). An intense and short stream discharge period occurred in autumn, when stream water infiltrated a maximum of $10 \mathrm{~m}$ into the riparian zone. Nitrate concentration and nitrate removal spatial rates $\left(\eta_{\mathrm{NO} 3}\right)$ showed wide spatial heterogeneity. Higher nitrate concentrations $\left(3.4 \mathrm{NO}_{3}-\mathrm{N} \mathrm{mg} \mathrm{L}^{-1}\right)$ and effective nitrate removal $\left(\eta_{\mathrm{NO} 3}=\right.$ $0.098 \pm 0.04 \mathrm{~m}^{-1}$ ) were found in the deep groundwater of hillslope zone associated to low water fluxes. In contrast, in the stream edge zone (with higher water fluxes), nitrate release predominated over depletion $\left(\eta_{\mathrm{NO} 3}=-0.13 \pm 0.04 \mathrm{~m}^{-1}\right)$ during the stream discharge period. This opposite pattern of nitrate removal observed in the study area suggests that the depletion of diffuse nitrate inputs in riparian zones bounded by intermittent streams requires careful consideration. INDEX TERMS: 1806 Hydrology: Chemistry of fresh water; 1831 Hydrology: Groundwater quality; KEYWORDS: riparian zone, Mediterranean streams, intermittent streams, nitrate, biogeochemistry, hydrology

Citation: Butturini, A., S. Bernal, E. Nin, C. Hellin, L. Rivero, S. Sabater, and F. Sabater, Influences of the stream groundwater hydrology on nitrate concentration in unsaturated riparian area bounded by an intermittent Mediterranean stream, Water Resour. Res., 39(4), 1110, doi:10.1029/2001WR001260, 2003.

\section{Introduction}

[2] Nonpoint source of dissolved organic and inorganic loads to surface and groundwater due to human activity are increasing [Guimerá, 1998]. Hence, research is intensifying into landscape environments that potentially might control the nitrogen transport and/or transformations in ecosystems [Correl, 1997]. Riparian and hyporheic zones can influence stream biogeochemistry [Bencala, 1993; Butturini and Sabater, 1998] and their detailed study is a priority to protect stream ecosystems [Meyer, 1997] and freshwater

\footnotetext{
${ }^{1}$ Now at Institute of Earth Sciences Jaume Almera (CSIC), Barcelona, Spain.

${ }^{2}$ Now at Departament Ecología Aquática, Universitat de Girona, Campus Montilivi, Girona, Spain.

Copyright 2003 by the American Geophysical Union. 0043-1397/03/2001WR001260\$09.00
}

resources [Standford, 1998]. Riparian and hyporheic zones represent transition zones where upstream water and groundwater converge. Field studies have pointed out that saturated near-stream areas are frequently subjected to seasonal and/or annual hydrologic changes which affect the relationship between biogeochemistry solute transport and the hydrology of stream aquifer system [Cirmo and McDonnell, 1997]. In addition, storm episodes determine changes in flow direction [Serrano and Workman, 1998] whereby water in the stream can move into the riparian zones [Haycock and Burt, 1993a].

[3] Certainly, the most studied biogeochemical process of the riparian zones is the reduction of nitrate from groundwater entering the stream [Jacobs and Gilliam, 1985; Gilliam, 1994; Hill, 1996; Komor and Magner, 1996]. Nitrate removal has been studied in humid-temperate zones with saturated riparian zones where exists a close connection between soil, vegetation, and the phreatic water for 
most of the year [Cirmo, 1997; Devito et al., 2000]. Unsaturated riparian environments, however, have received little attention, and field data are limited to a few arid or semi-arid streams [Newman et al., 1998; Martí et al., 2000].

[4] In order to investigate whether the riparian zone acts as a source or sink of nitrate, the stream aquifer hydrology and nitrate fluxes in groundwater were examined in an unsaturated riparian forest, which is bounded by an intermittent Mediterranean stream and an agricultural field. The riparian groundwater hydrology was studied during two years (1998-2000) following the changes of groundwater levels. Monitoring allowed the estimation of groundwater inputs within the riparian area, when the stream water discharges in the riparian aquifer, and where the stream and the hillslope groundwater converge.

\section{Study Site}

[5] The study site is located in a granitic catchment (Fuirosos) of $16 \mathrm{~km}^{2}$ at an altitude of $150 \mathrm{~m}$, near Barcelona in the northeast of Spain (latitude $41^{\circ} 42^{\prime} \mathrm{N}$, longitude $2^{\circ} 34^{\prime}$ ). The forest (oak holm, coniferous and deciduous) covered

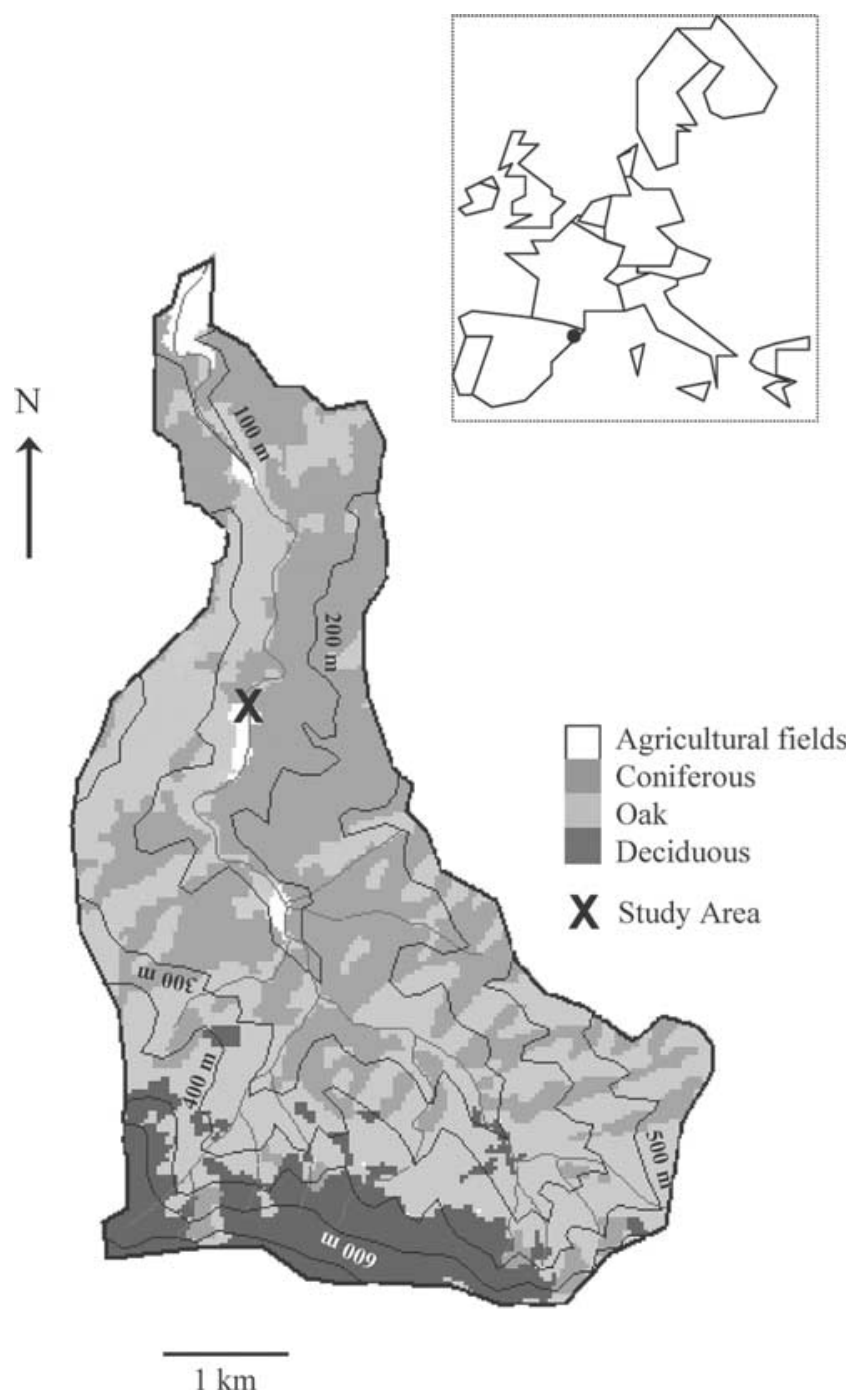

Figure 1. Map showing the Fuirosos catchment and the location of the riparian study area.

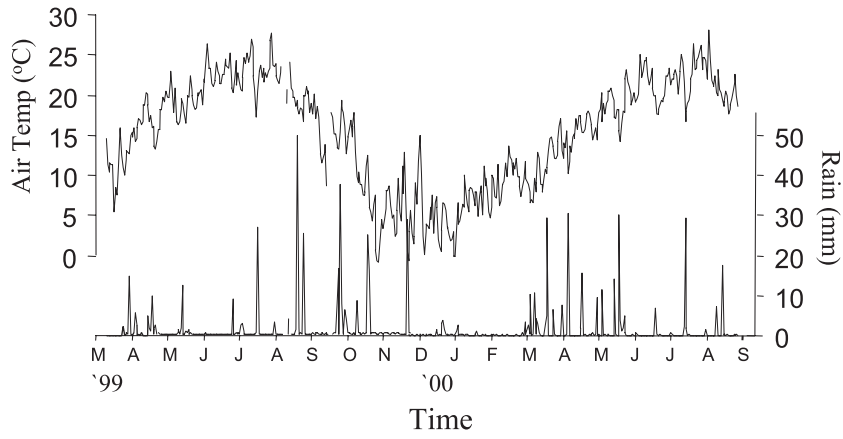

Figure 2. Temporal dynamics of air temperature and daily precipitation in the Fuirosos catchment during the study period.

$90 \%$ of the total catchment area (Figure 1). Climate is typically Mediterranean with mean annual temperature ranging from $3^{\circ} \mathrm{C}$ in January to $24^{\circ} \mathrm{C}$ in August. Mean annual precipitation is $613 \mathrm{~mm}$ (Figure 2) [Butturini et al., 2002].

[6] Annual bulk precipitation of nitrogen averaged $0.41 \mathrm{~g}$ $\mathrm{N} \mathrm{m}^{-2} \mathrm{y}^{-1}$ [Bernal et al., 2003]. The riparian study plot was a forested zone of $55 \mathrm{~m}$ length and $18 \mathrm{~m}$ wide, situated between the stream and a small agricultural field (1.1 ha). A plantation of London plane tree (Platanus acerifolia) and alders (Alnus glutinosa), along the stream edge, dominated the riparian vegetation. The estimated leaf input was $0.5 \mathrm{~kg}$ $\mathrm{dw} \mathrm{m}^{-2}\left(5.2 \mathrm{~g} \mathrm{~N} \mathrm{~m}^{-2}\right.$ [Sabater et al., 2002, 2003]).

[7] The stream is intermittent and is dry from the end of June until September. From October, the base flow ranged between 5 and $20 \mathrm{~L} \mathrm{~s}^{-1}$. Groundwater never saturated the upper soil organic layer, and soil-water volumetric content ranges from $8 \%$ in summer, to $25 \%$ in winter [Butturini et al., 2002].

[8] The adjacent agricultural field was cultivated with corn. In December 1998 it was fertilized with inorganic fertilizer (NPK, 8.5\% ammonia, 6.5\% nitrite) to a final nitrogen input of $24 \mathrm{~g} \mathrm{~N} \mathrm{~m}^{-2}$.

\section{Material and Methods}

\subsection{Groundwater Monitoring and Geological Characterization}

[9] In the riparian study area, 24 wells were placed arranged in a regular grid (4 rows and 6 lines). The study plot was divided in three zones: the stream edge zone, between rows 1 and 2, adjacent to the stream channel ( $20 \%$ of the total area); the hillslope zone, between rows 3 and 4 , adjacent to the agricultural field (50\% of total area); and the midzone, between rows 2 and 3 (30\% of the total area) (Figure 3a). Groundwater levels were monitored manually in each well, every 5-15 days from May 1998 until September 2000. Wells were made by digging PVC tubes $(15 \mathrm{~cm}$ ) with depths between $1 \mathrm{~m}$ (near the stream edge) to $7 \mathrm{~m}$ (near the agric. field). Wells were uniformly perforated along their length. Wells located near the stream channel (row 1) penetrated the sandy-gravel profile, while well rows 2 to 4 perforated the sandy-gravel layer and the weathered granite layer (Figure 4a).

[10] Stream water and groundwater level in well $2_{2}$ (i.e., in the stream edge zone, Figure 3 a) were continuously 


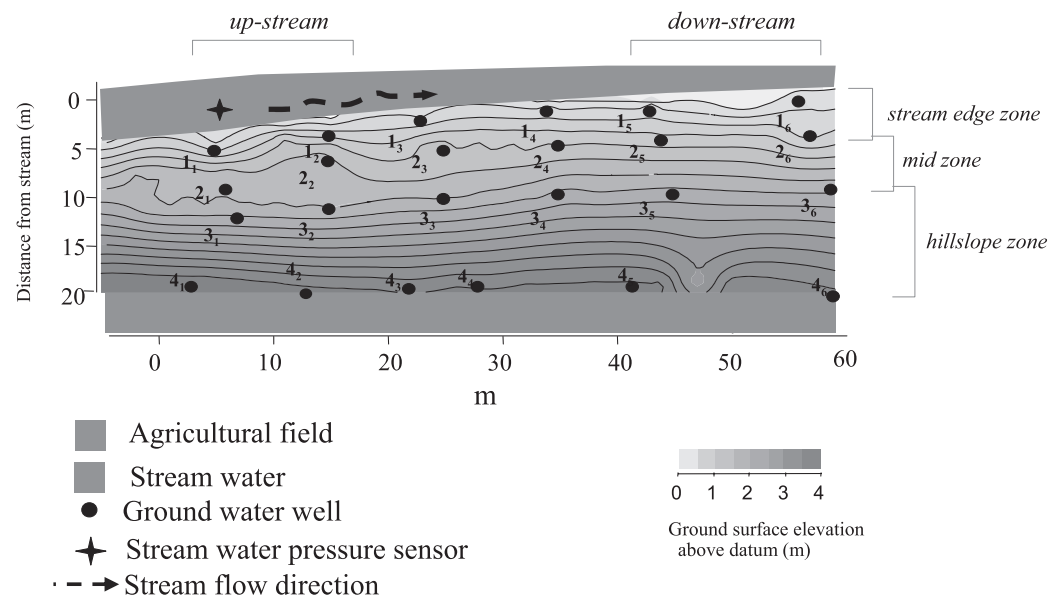

b

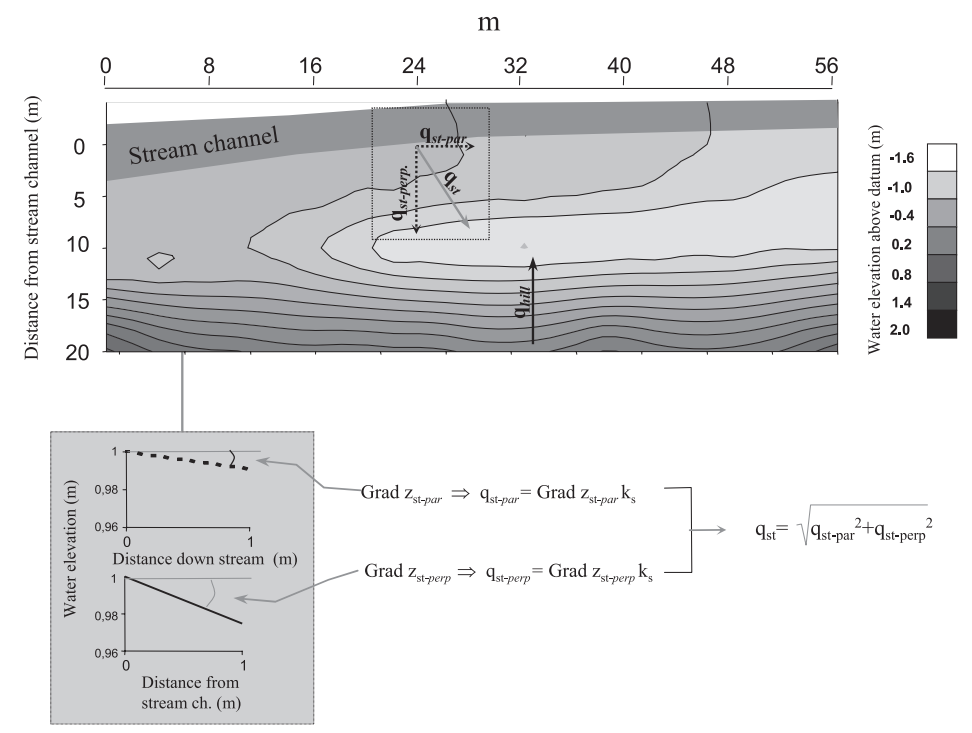

Figure 3. (a) Vertical view of the riparian study site showing the ground surface elevation and the location of the riparian wells. (b) Schematic representation of the specific discharge estimation in the near stream (see text for detailed explanation).

monitored using water pressure sensors connected to a data logger (Campbell $\left.{ }^{\odot} \mathrm{CR} 10 \mathrm{X}\right)$ during the entire study period. [11] Saturated horizontal hydraulic conductivity $\left(k_{s}\right.$, $\mathrm{m} \mathrm{d}^{-1}$ ) was determined using the Hovrsley bail tests [Batu, 1998]. Hydraulic conductivities measured from wells in row 1 represented the upper soil layer conductivity. For remaining wells, the hydraulic conductivity corresponded with both the deep weathered granite layer and the overlying sandy-gravel layer. During winter 2000, 4 additional shallow wells were placed along row 3 to measure hydraulic conductivity in the upper soil layer. Additional geological information was obtained using the refractory seismic method. This technique allowed the detection of the depth of the granite bed rock (thereafter GBR) and the thickness of the weathered bed rock layer (thereafter WBR) and the sandy-gravel layer (thereafter SG) [Reynols, 1997]. We performed 11 refraction seismic profiles (7 perpendicular and 4 parallel to the stream channel). Subsoil lithological profiles were drawn from propagation velocities of the seismic waves ( weathered rock bed $=1.40-2.40 \mathrm{~km} / \mathrm{s}$ : rock bed $=3.50-$ $4.50 \mathrm{~km} / \mathrm{s}$, [Reynols, 1997]).

\subsection{Hydraulic Gradients}

[12] Within the riparian study area, the hydraulic gradients perpendicular to the stream channel (thereafter " $\mathrm{grad}$ $z$ ") were estimated in (1) the hillslope zone ( $\left.\operatorname{grad} z_{h l l}\right) ;(2)$ in the stream edge zone ( $\left.\operatorname{grad} z_{s t-p e r p .}\right)$ and in the midzone $\left(\operatorname{grad} z_{\text {mid }}\right)$. Positive perpendicular hydraulic gradient values indicated water direction from the hillslope to the stream, while negative values indicated the opposite water-flow direction (i.e., stream discharge). The hydraulic gradient parallel to the stream (grad $z_{s t-p a r}$ ) was exclusively estimated for the stream edge zone. In the hillslope zone, the 

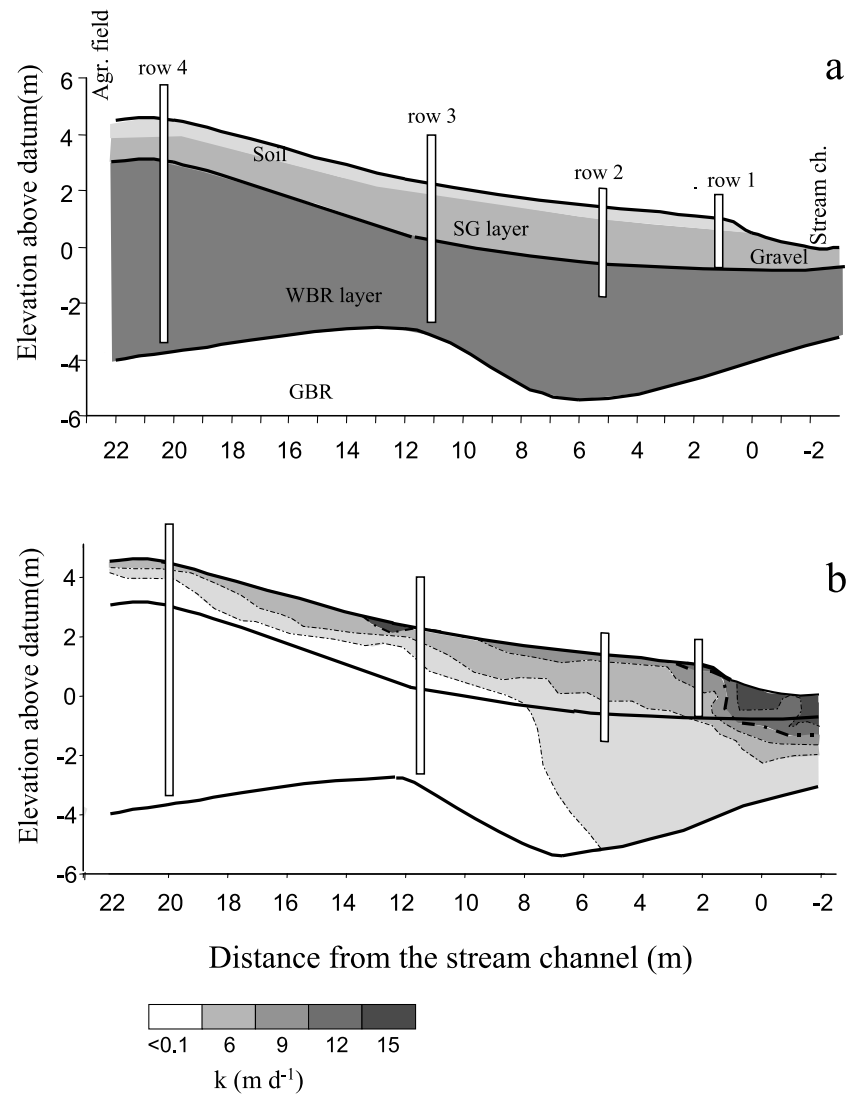

Figure 4. Cross section of the riparian study site showing (a) lithology profiles and (b) saturated hydraulic conductivity. SG is the soil-gravel layer; WBR is the weathered rock layer; GBR is the granite rock bed.

hydraulic gradient parallel to the stream channel was negligible in comparison to the perpendicular one.

\subsection{Groundwater Fluxes}

[13] Groundwater specific daily discharges $\left(\mathrm{q}=k_{s} \cdot \operatorname{grad}\right.$ $z, \mathrm{~m} \mathrm{~d}^{-1}$, [Freeze and Cherry, 1979]) were estimated in the hillslope zone $\left(\mathrm{q}_{h l l}\right)$ and in the stream edge zone $\left(\mathrm{q}_{s t}\right)$ under different hydrological conditions. In the stream edge zone, the specific discharge $\left(\mathrm{q}_{s t}\right)$ is calculated by the vectorial sum of specific discharges perpendicular $\left(\mathrm{q}_{\text {st-perp }}\right)$ and parallel $\left(\mathrm{q}_{s t-p a r}\right)$ to the stream channel (Figure 3b).

[14] The stream edge zone was discharged by the stream (i.e., reverse specific flux) when the following conditions concurred:

$$
\begin{aligned}
& \operatorname{grad} z_{s t-p e r p}<0 ; \\
& \frac{\left|\operatorname{grad}_{z_{s t}-\text { perp }}\right|}{\left|\operatorname{grad}_{z_{s t}-\text { par }}\right|}>1
\end{aligned}
$$

[15] When these two conditions were not found, the main flux was considered parallel to the stream channel. For clarity in plots, reverse fluxes are indicated with $\mathrm{q}_{s t}<0$.

[16] Total daily groundwater fluxes (thereafter $\mathrm{Q}, \mathrm{m}^{3} \mathrm{~d}^{-1}$ ) in the riparian study area are calculated as the product of the specific discharge times the cross-sectional area (i.e., section perpendicular to the main flow direction). The cross sectional area depended on the depth of the granitic rock bed. In the hillslope zone, the total cross-sectional area ranged between $200 \mathrm{~m}^{2}$ and $290 \mathrm{~m}^{2}$, In the stream edge zone, the total crosssectional area ranged between $44 \mathrm{~m}^{2}$ (when the main flux was parallel to the stream channel) and $265 \mathrm{~m}^{2}$ (exclusively during the reverse flux period). In addition, groundwater daily fluxes perpendicular to the stream channel are given per unit length of stream length $\left(\mathrm{m}^{3} \mathrm{~d}^{-1} \mathrm{~m}^{-1}\right)$. Groundwater fluxes in the stream edge zone have been associated to those found in the hyporheic zone [Triska et al., 1989].

\subsection{Chloride Concentration and Nitrate Removal Estimation}

[17] Spatial heterogeneity of chloride concentration in groundwater was used to delimit zones in the study area where the mixing between hillslope groundwater and the infiltrated stream water was negligible [Altman and Parizek, 1995]. Thus the mixing was considered negligible, in a given zone, when the chloride concentration was identical in the sampled wells and covaried in time.

[18] Once the groundwater fluxes in the riparian study area were calculated, relative nitrate removal (or release) rates $\left(\eta_{\mathrm{NO} 3}\right)$ were estimated in selected zones without mixing between hillslope groundwater and infiltrated stream water, using the following input output mass balance formula:

$$
\eta_{\mathrm{NO}}=\frac{F_{I}-F_{0}}{F_{I}} \Delta x^{-1} \quad\left(\mathrm{~m}^{-1}\right)
$$

[19] Where $\mathrm{F}_{\mathrm{I}}$ and $\mathrm{F}_{\mathrm{O}}$ are daily nitrate fluxes $\left(\mathrm{N} \mathrm{mg} \mathrm{d}^{-1}\right)$, in input and output wells respectively, through a section perpendicular to flow direction. $\Delta x$ is the distance (m) between input and output wells. Nitrate fluxes, through selected riparian portions, were calculated as total daily fluxes $\left(\mathrm{Q}, \mathrm{m}^{3} \mathrm{~d}^{-1}\right)$ times nitrate concentration. Nitrate depletion means $\eta_{\mathrm{NO} 3}>0$. The relative nitrate removal spatial rates $\left(\eta_{\mathrm{NO} 3}\right)$ allowed us to compare the nitrate removal in different zones of the riparian plot subjected to groundwater fluxes of different magnitudes.

\subsection{Water Chemistry}

[20] Prior to groundwater sampling, at least a volume of standing water in the well was removed. Water samples were filtered through pre-ashed fiberglass filters (Whatman ${ }^{\text {B }}$ $\mathrm{GF} / \mathrm{F}$ ), cold-stored for $24-48 \mathrm{~h}$ and analyzed for $\mathrm{Cl}, \mathrm{NO}_{3}$ and dissolved organic carbon (thereafter DOC). Inorganic solutes were analyzed by capillary electrophoresis (Waters ${ }^{\mathbb{B}}$, CIA-Quanta 5000 [Romano and Krol, 1993]). DOC samples were analyzed between May 1998 and March 1999 using a high-temperature catalytic oxidation Shimadzu TOC 5000 analyzer.

[21] In summer 1998 and winter 1999, dissolved oxygen concentration was measured in the groundwater using a $\mathrm{WTW}^{\mathrm{B}} \mathrm{O}_{2}$ probe.

\section{Results}

\subsection{Hydraulic Conductivity and Lithological Profiles}

[22] The granitic rock bed is located $3.3 \pm 0.2 \mathrm{~m}$ (mean \pm $\mathrm{SD})$ below the streambed and $8.2 \pm 2.6 \mathrm{~m}$ below the agricultural field. Overlying the rock bed there are a weathered granite layer (WBR layer) 2 to $11 \mathrm{~m}$ thick and a gravelsandy soil layer (SG layer) 0.8 to $2.8 \mathrm{~m}$ thick (Figure $4 \mathrm{a}$ ). 


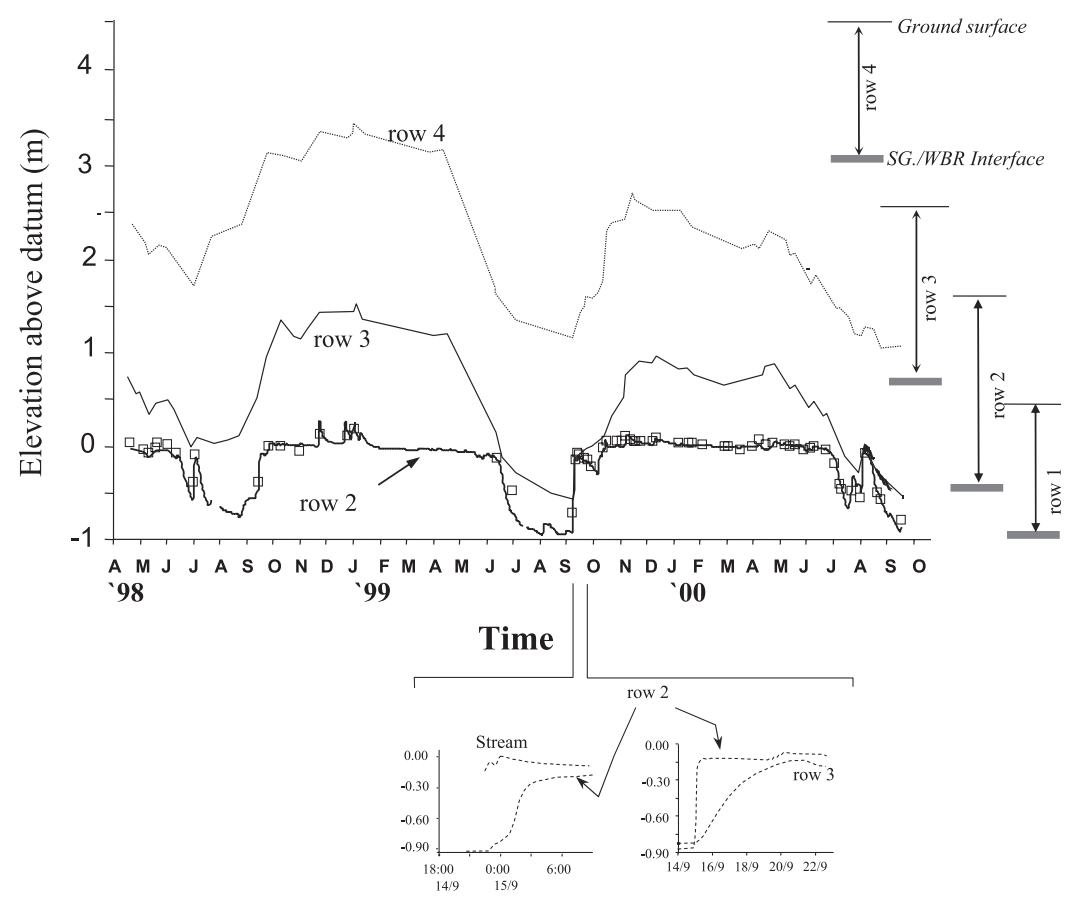

Figure 5. Temporal dynamics of average head elevation in riparian groundwater in each row of wells (thick horizontal lines and shaded bars show the average ground surface and SG/WBR interface elevation in each row). Squares are data from row 1. The inset shows detailed time changes in stream edge groundwater and stream level during the stream discharge period.

[23] The saturated hydraulic conductivity $\left(k_{s}\right)$ in the riparian sediments averaged $5 \pm 6.5 \mathrm{~m} \mathrm{~d}^{-1}(\mathrm{n}=24)$. The conductivity values in the SG layer were obtained from wells in row 1, near the stream channel, and ranged between $12 \mathrm{~m} \mathrm{~d}^{-1}$ and $19 \mathrm{~m} \mathrm{~d}^{-1}$, meanwhile, the underlying WBR layer of the stream edge zone (obtained from wells in row 2) averaged $4.8 \pm 3.12 \mathrm{~m} \mathrm{~d}^{-1}$. In the hillslope zone the hydraulic conductivities refer to the deeper WBR layer (i.e., below $3.5 \mathrm{~m}$ depth) and averaged 9.6 $10^{-3} \pm 3.7$ $10^{-3} \mathrm{~m} \mathrm{~d}^{-1}$ and were much lower than those estimated in the near stream zone. During winter 2000-2001, anomalous high groundwater levels near the wells in row 3 , allowed to measure the saturated hydraulic conductivity of SG layer at $0.5 \mathrm{~m}\left(13 \pm 0.5 \mathrm{~m} \mathrm{~d}^{-1}\right)$ and $1 \mathrm{~m}\left(0.1 \pm 0.07 \mathrm{~m} \mathrm{~d}^{-1}\right)$ below ground surface (Figure $4 \mathrm{~b}$ ).

\subsection{Temporal and Spatial Dynamics of Groundwater Levels}

[24] The groundwater table never saturated the upper organic soil surface. Its depth, with respect to the ground surface ranged between $3.4 \mathrm{~m}$ (hillslope zone) in summer and $0.5 \mathrm{~m}$ (near stream zone) in winter. In the hillslope zone, the groundwater levels covaried $\left(\mathrm{r}^{2}=0.83\right.$, d.f. $=64, \mathrm{P}<$ 0.001 ) and followed a clear seasonal pattern with high levels from November to May. In hillslope zone, groundwater saturated the deep WBR layer during the whole study period. The overlying SG layer was partially saturated only between October 1998 and May 1999. In the midzone, the SG layer was partially saturated from October 1998 to May in 1999 and from November 1999 to May in 2000 (Figure 5).

[25] In the stream edge zone, groundwater levels strongly covaried $\left(\mathrm{r}^{2}=0.95\right.$, d.f. $\left.=62, \mathrm{p}<0.001\right)$ following the stream water level pattern. The groundwater level was nearly steady from late October until June. From June-July onwards, the levels decreased rapidly (at a rate of $0.2 \mathrm{~cm} \mathrm{~h}^{-1}$ ) and the stream was dry during all summer. Groundwater level was abruptly recovered (at a rate of $10 \mathrm{~cm} \mathrm{~h}^{-1}$ ) with the first seasonal storm in late September-October (Figure 5 inset). The SG layer was partially saturated from late September until June.

[26] Figure 6 shows the temporal dynamics of the hydraulic gradients from June 1999 until September 2000. In the hillslope the grad $z_{\text {hll }}$ averaged $0.17 \pm 0.025$ increasing to 0.2 in October-November. The grad $z_{\text {mid }}$ showed larger oscillation than grad $z_{h l l}$, with low gradients $(<0.05)$ from July to October. From December to May $\operatorname{grad} z_{\text {mid }}$ approached grad $z_{\text {hll }}$ (Figure 6a). In the stream edge zone, the average grad $z_{\text {st-perp }}$ was slightly negative $(-0.002 \pm$ $0.07 \mathrm{SD}$ ) with negative peaks during summer and autumnal storms. In this zone, $\left|\operatorname{grad} z_{s t-p a r}\right|>\left|\operatorname{grad} z_{\text {st-perp }}\right| \operatorname{most}$ of time, therefore main groundwater flow direction was parallel to the stream channel $\left(\left|\operatorname{grad} z_{s t-p e r p}\right| /\left|\operatorname{grad} z_{s t-p a r}\right|=0.2 \pm\right.$ 0.16 , Figure 6b).

[27] Groundwater levels and gradient changes showed a mixing of the hillslope groundwater and the infiltrated stream water. The location of the slope change of groundwater table in the riparian plot $(\Delta S$, Figure 7$)$, shows the mixing front where these two water bodies converge during a hydrological year. During the first autumnal storm event of late September, after the summer drought, (i.e., grad $z_{\text {st-perp }}<0$ and $\left.\left|\operatorname{grad} z_{\text {st-perp }}\right|>\left|\operatorname{grad} z_{\text {st-par }}\right|\right)$ stream water infiltrated 8-10 $\mathrm{m}$ into the riparian area (Figure 7a, surface plots 14/09/1999 and 15/09/1999, and Figure 7b). The mixing front then moved back to the stream channel at a 


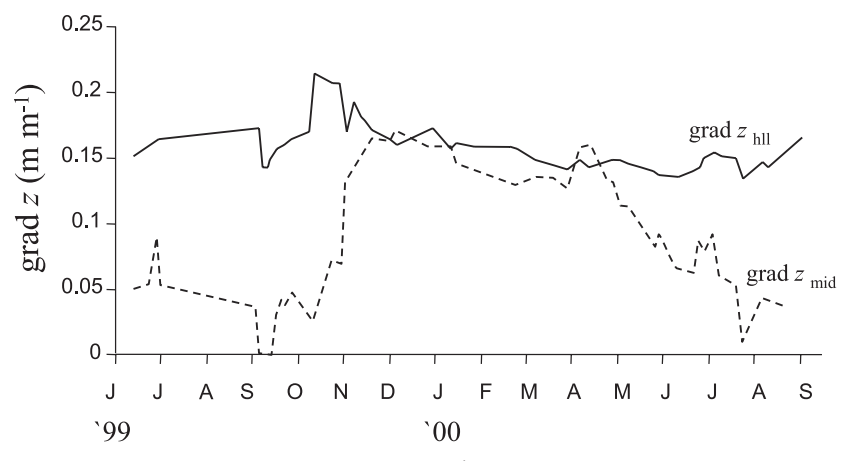

Time a

b
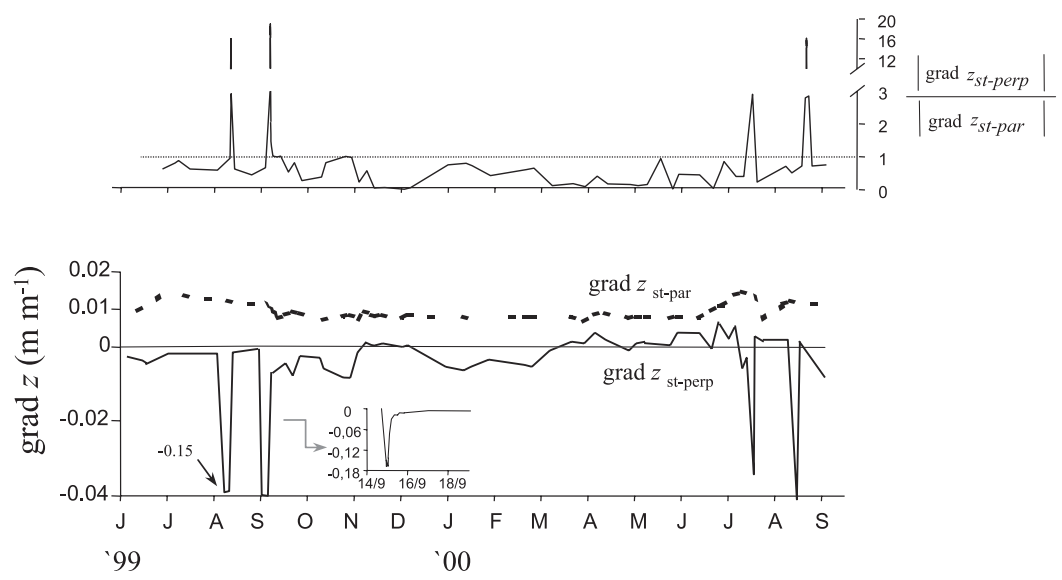

Time

Figure 6. (a) Temporal dynamics of hillslope and midzone gradients (grad $z_{\text {hll }}$ and grad $z_{\text {mid. }}$ (b) Temporal dynamics of stream edge gradients and associated ratio $\left(\operatorname{grad} z_{s t \text {-perp }}\right.$ and $\left.\operatorname{grad} z_{s t-p a r}\right)$. The inset shows detailed time changes during the stream discharge period.

rate of $\sim 0.1 \mathrm{~m} \mathrm{~d}^{-1}$ until December (Figure 7a, surface plot 13/12/1999 and Figure 7b). Between December and June, the mixing front remained located $3 \mathrm{~m}$ from the stream channel (Figure 7b).

\subsection{Groundwater Fluxes in the Riparian Zone: Stream Discharge Versus Hillslope Recharge}

[28] Three periods were distinguished within a hydrologic year: (1) the autumnal stream discharge period (late September-October); (2) the winter-spring groundwater hillslope recharge period (November-May); (3) the summer dry period (June-late September).

[29] During the stream discharge period, the abrupt rise of the groundwater level in the stream edge zone (Figure 5a inset), and high hydraulic conductivity values in the SG and WBR layers, determined flushing peaks of reverse specific discharges $\left(\mathrm{q}_{s t}\right)$ of $1.5 \mathrm{~m} \mathrm{~d}^{-1}$ (in SG layer) and $0.5 \mathrm{~m} \mathrm{~d}^{-1}$ (in WBR layer). The reverse $\mathrm{q}_{s t}$ disappeared 7-10 days after the first autumnal storm event. Afterwards, the grad $z_{s t-p e r p}$ was negligible, (i.e., $\left|\operatorname{grad} z_{s t-p a r}\right|>\left|\operatorname{grad} z_{\text {st-perp }}\right|$, Figure $6 b)$, therefore parallel specific discharges predominated over the perpendicular ones (i.e., $\mathrm{q}_{s t-p a r}>\mathrm{q}_{\text {st-perp }}$ ) and $\mathrm{q}_{\mathrm{st}}$ averaged $0.08 \mathrm{~m} \mathrm{~d}^{-1}$ in the SG layer and $0.03 \mathrm{~m} \mathrm{~d}^{-1}$ in the WBR layer (Figure 8a). In the hillslope zone the specific discharge $\left(\mathrm{q}_{h l l}\right)$ was extremely low because groundwater flowed through the low conductive WBR layer $\left(1.710^{-3} \pm\right.$ $210^{-4} \mathrm{~m} \mathrm{~d}^{-1}$; Figure 8a).

[30] The winter-spring groundwater recharge period began when the hillslope groundwater increased its level and saturated the most conductive SG sediments. Consequently, $\mathrm{q}_{\text {hll }}$ remained low through the WBR layer, but increased to $1510^{-3} \mathrm{~m} \mathrm{~d}^{-1}$ in the SG layer (Figure $8 \mathrm{a}$ ). This led to the formation of a perched water table flowing downslope determining the rapid recession of the mixing front toward the stream channel (Figure 7b).

[31] In summer, the SG layer remained unsaturated, and groundwater in the hillslope zone flowed through the WBR layer at a specific discharge of $1.510^{-3} \pm 4$ $10^{-4} \mathrm{~m} \mathrm{~d}^{-1}$. In the stream edge zone, the grad $z_{\text {str-perp }}$ was approximately nil, hence $\mathrm{q}_{s t-p e r p} .=0$, and $\mathrm{q}_{s t}=$ $\mathrm{q}_{\text {st }- \text { par }}=0.03 \mathrm{~m} \mathrm{~d}^{-1}$.

[32] The estimated total daily groundwater flux in the hillslope zone $\left(\mathrm{Q}_{h l l}\right)$ approached $0.3 \mathrm{~m}^{3} \mathrm{~d}^{-1}$ (per unit length of the stream channel is $5.510^{-3} \mathrm{~m}^{3} \mathrm{~d}^{-1} \mathrm{~m}^{-1}$ ) during the stream discharge and the dry periods when the groundwater saturated only the WBR layer (cross-sectional area ranging from 200 to $264 \mathrm{~m}^{2}$ ). On the other hand, during the hillslope recharge period, the total groundwater daily fluxes ranged between 0.85 and $0.55 \mathrm{~m}^{3} \mathrm{~d}^{-1}\left(1.510^{-2}\right.$ and $10^{-2} \mathrm{~m}^{3} \mathrm{~d}^{-1}$ $\mathrm{m}^{-1}$; cross-sectional area ranging from 265-290 $\mathrm{m}^{2}$ ) with 

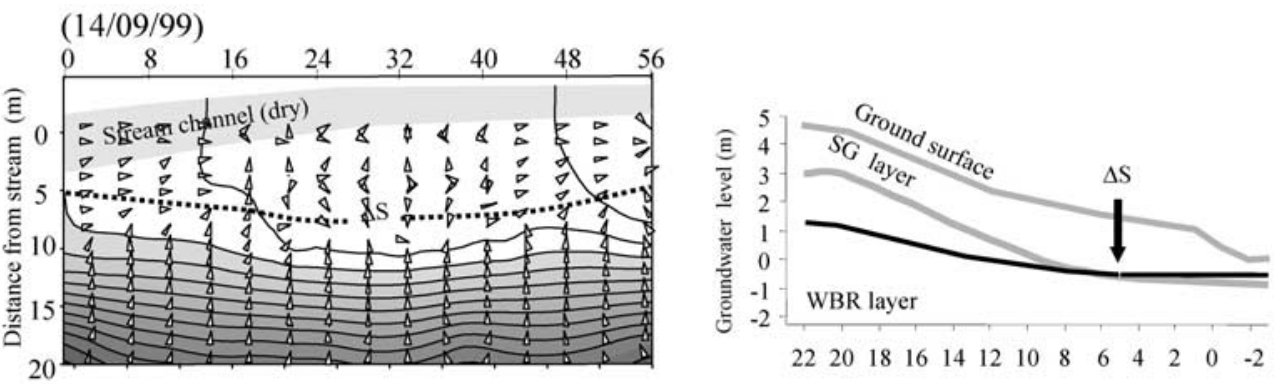

$\mathrm{a}$

\section{$(15 / 09 / 99)$}
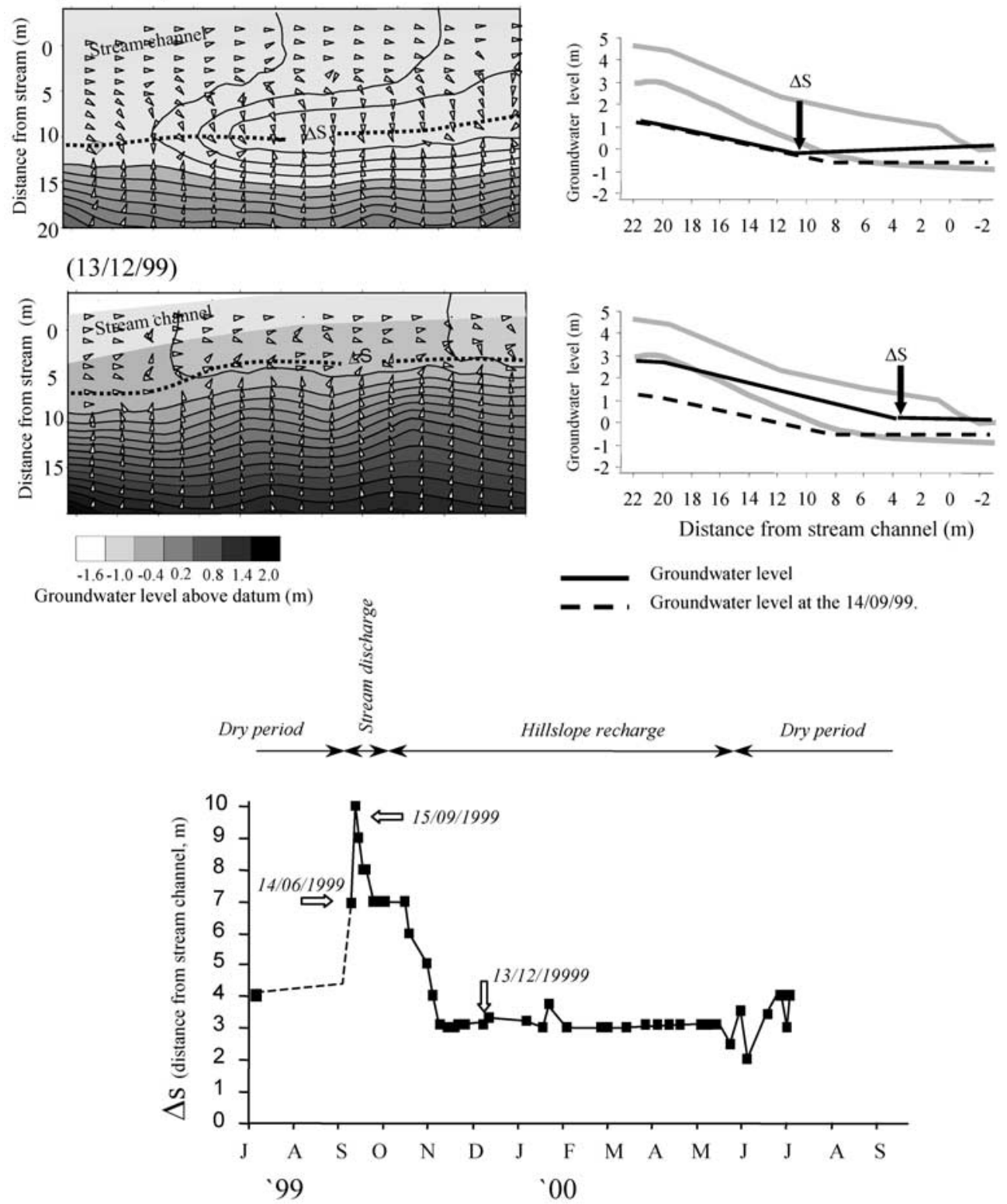

Time (months)

Figure 7. (a) Groundwater level surface and gradient vector field plots and associated cross sections during three selected moments of the hydrological year. Vector field plot shows the groundwater flow direction. Arrows in the cross section show the location of the slope change of the groundwater table $(\Delta \mathrm{S})$. (b) Temporal dynamics of the location of $\Delta \mathrm{S}$ during an hydrological year. Groundwater level surface and gradient vector field plots were generated with Mathematica software [Wolfram, 1991]. 
Specific Flux: Hillslope zone

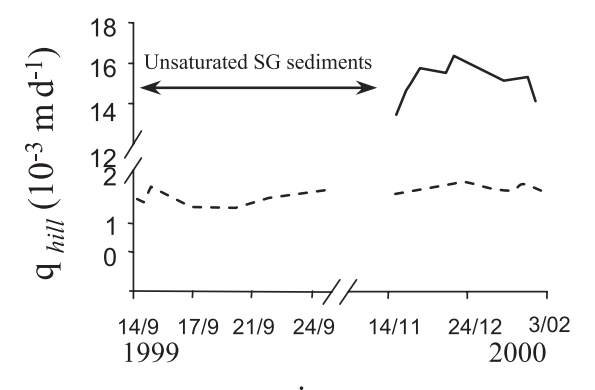

time
Specific Flux: Stream edge zone

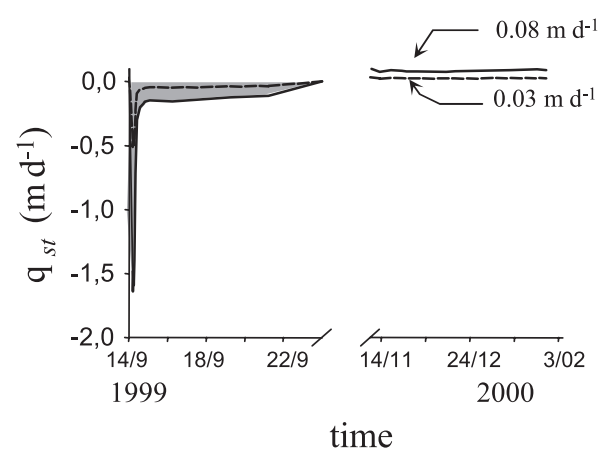

Specific discharge in SG layer

Specific discharge in WBR layer<smiles>C1=CCCC=C1</smiles>

Total flux: Hillslope zone

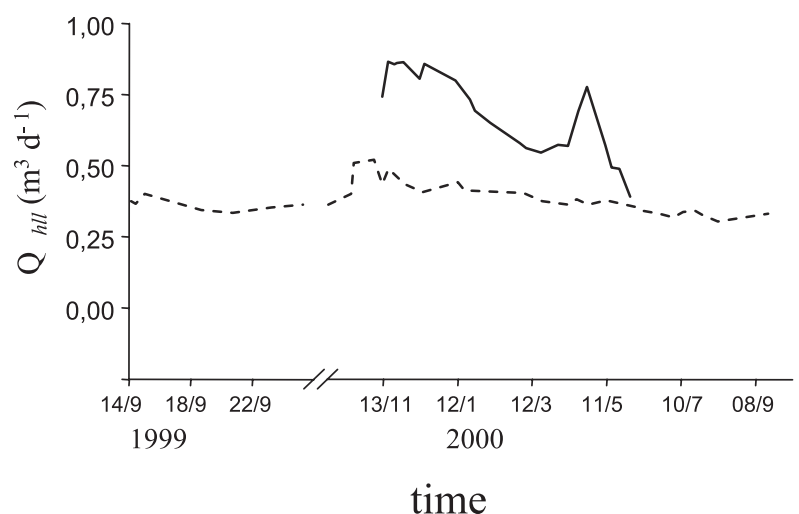

Total flux: Stream edge zone
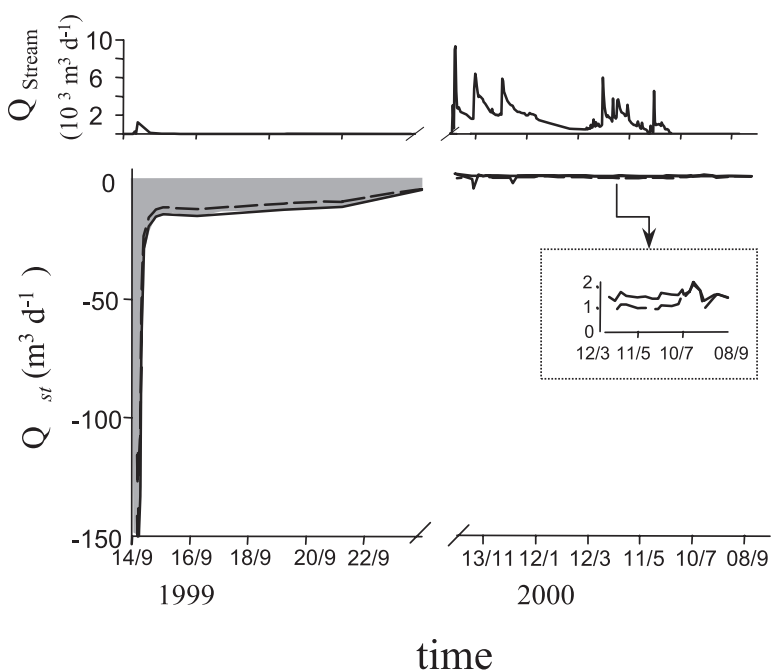

$\begin{array}{ll}\text { _. } & \text { Total discharge in SG layer } \\ \text { _. _ } & \text { Total discharge in WBR layer }\end{array}$

Figure 8. (a) Temporal changes in specific daily discharges ( $\mathrm{q}, \mathrm{m} \mathrm{d}^{-1}$ ), in the hillslope and stream edge zones, during the stream discharge and the hillslope recharge periods. (b) Temporal changes in total daily discharge in the hillslope $\left(\mathrm{Q}_{\mathrm{hll}}, \mathrm{m}^{3} \mathrm{~d}^{-1}\right)$ and stream edge zones $\left(\mathrm{Q}_{\mathrm{st}}, \mathrm{m}^{3} \mathrm{~d}^{-1}\right)$ during the hydrological year with special emphasis of the stream discharge period. Shaded area in graphs shows the reverse flux (when the stream discharged into the riparian zone).

flow through the SG layer that ranged from $8 \%$ to $55 \%$ of the total daily flux (Figure 8b).

[33] In the stream edge zone, total daily fluxes $\left(\mathrm{Q}_{s t}\right)$ were much more variable and flashy. During the reverse flux peak, we estimated a maximum flow of $150 \mathrm{~m}^{3} \mathrm{~d}^{-1}\left(2.7 \mathrm{~m}^{3}\right.$ $\mathrm{d}^{-1} \mathrm{~m}^{-1}$ ) during a few hours into the near-stream zone (cross-sectional area of $265 \mathrm{~m}^{2}$ ). In 7-10 days, the reverse flux was replaced by a flux parallel to the stream $\left(\mathrm{Q}_{s t}=1.5 \pm\right.$
$0.2 \mathrm{~m}^{3} \mathrm{~d}^{-1}$ ) and the cross-sectional area decreased to $44 \pm$ $2 \mathrm{~m}^{2}$. In this zone the groundwater flow through the SG layer contributed to $5-55 \%$ of the total daily flux (Figure $8 \mathrm{~b}$ ).

\subsection{Groundwater Chemistry}

[34] Chloride concentration in groundwater wells ranged widely, from 10 to $70 \mathrm{mg} \mathrm{L}{ }^{-1}$, without a clear seasonal pattern (Figure 9a). The hillslope zone had low chloride 
content, while concentration was higher in the stream edge zone (Table 1). Within the hillslope and stream edge zones, chloride concentrations strongly covaried and fitted the $1: 1$ line during the hillslope recharge and the dry periods. On the other hand, the cross correlation decreased in the midzone when chloride content in row 3 was compared to that found in the adjacent stream edge row 2 (Figure 9b). This result evidenced that the mixing between hillslope and stream edge groundwaters occurred in the midzone between rows 3 and 2. However, during the hillslope recharge period (November-April) chloride concentration in the stream edge wells located up-stream (wells $2_{1}$ and $2_{2}$ ) approached and covaried with that found in the adjacent hillslope wells (wells $3_{1}$ and $3_{2}, \mathrm{r}^{2}=0.85$, d.f. $=25, \mathrm{p}<0.001$ ). This indicated that the mixing between hillslope groundwater and stream edge groundwater got closer to the stream channel during this period in the upstream riparian study area.

[35] Nitrate concentrations showed a gradual decrease along the riparian transect. Lowest concentrations were found in stream water and in stream edge groundwater, whereas the highest concentrations were observed in row 4 adjacent to the agricultural field (Table 1 and Figure 10). Since the storm period of October 1999, nitrate concentrations in row 4 were three times higher than those measured previously. This abrupt change occurred one year just after the agricultural fertilization. In the remaining wells, a slight increase in nitrate concentration was only observed in up-stream wells $3_{1}, 3_{2}$ and $2_{2}$.

[36] Within the hillslope zone, the chloride data (Figure $9 \mathrm{~b}$, first plot) and changes in groundwater level (Figure 5a) indicated that mixing between hillslope groundwater and stream edge groundwater was negligible during the hillslope recharge and dry periods. Therefore chemical and hydrometric data do not evidence that the decrease of nitrate concentration in hillslope groundwater observed between rows 4 and 3 (Figure 10) might be attributed to nitrate dilution by stream water with low nitrate concentration that flows through the stream edge zone. In the hillslope zone, ( $50 \%$ of the total studied area), 9 to $100 \%$ of groundwater nitrate inputs disappeared within $8 \mathrm{~m}$ of the riparian linear length. The nitrate fluxes were estimated in the up-stream hillslope zone (cross-sectional area ranging between 40 and $60 \mathrm{~m}^{2}$ ) and in the down-stream hillslope zone (cross sectional area ranging between 43 and $48 \mathrm{~m}^{2}$ ). Nitrate remove clearly predominate over release and the absolute removed nitrate flux ranged between 14 and $2100 \mu \mathrm{g} \mathrm{N}-\mathrm{NO}_{3} \mathrm{~d}^{-1}$. The relative removal spatial rate $\left(\eta_{\mathrm{NO} 3}\right)$ averaged $0.098 \pm$ $0.04 \mathrm{~m}^{-1}$ with considerable inter-annual variability but without a clear seasonal pattern. In fact, both the lowest and highest $\eta_{\mathrm{NO} 3}$ were measured in September-October 1998 and 1999 respectively (Figure 11a).

[37] Concerning the midzone, between the hillslope and stream edge zones, the hydrology was characterized by a complex flow path with a continuous mixing between the hillslope and stream groundwaters that limited a solid estimation of $\eta_{\mathrm{NO} 3}$ in the entire zone. Nevertheless, during the hillslope recharge period, the chloride data indicated that hillslope groundwater flow through upstream wells $2_{1}$ and $2_{2}$ (cross sectional area ranging between 55 and $63 \mathrm{~m}^{2}$ ) allowing the estimation of $\eta_{\mathrm{NO}}$ in this small portion of the midzone $(10 \%$ of the total studied area). Figure 11a shows

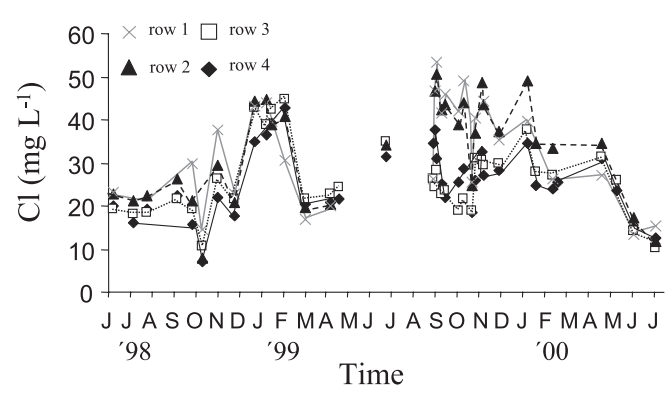

a

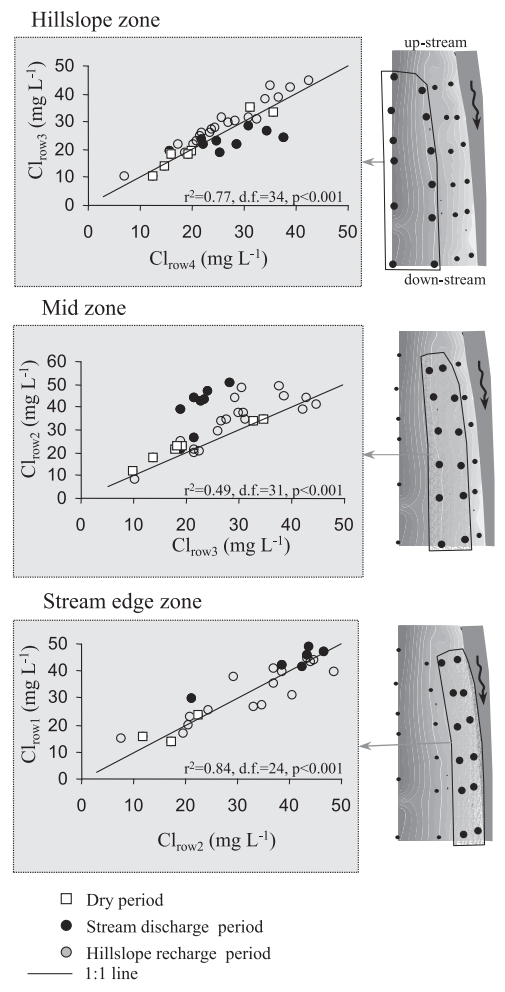

Figure 9. (a) Changes in average chloride concentrations in riparian groundwater during the study period. (b) Chloride cross correlations among adjacent rows.

that in this portion the $\eta_{\mathrm{NO} 3}$ ranged between $-1.6 \mathrm{~m}^{-1}$ (strong nitrate release) and $0.25 \mathrm{~m}^{-1}$.

[38] In the stream edge zone $(20 \%$ of the total area studied), the detailed groundwater sampling during the short stream discharge period of 1999, allowed to estimate $\eta_{\mathrm{NO} 3}$ when reverse flows occurred. After an initial nitrate peak in stream water, nitrate concentrations in rows 1 and 2 were higher than in the stream water (Figure 9 inset). Concentrations ranked row $2>$ row $1>$ Stream water, meanwhile the water flow was from stream water to row 2. Therefore between rows 1 and 2, nitrate was mobilized into groundwater and $\eta_{\mathrm{NO} 3}$ was negative $\left(\eta_{\mathrm{NO} 3}=-0.13 \pm\right.$ 0.04, Figure 10c).

[39] DOC concentrations in groundwater ranged between 0.5 and $6.0 \mathrm{mg} \mathrm{L}^{-1}$, with a gradual increase from the hillslope to the stream edge area. Row 1 and stream water were not significantly different. A significant DOC decrease was observed in row 2 approaching the concentrations measured in wells in rows 3 and 4 (Table 1). 
Table 1. Chloride, Nitrate and DOC Mean Concentrations $( \pm \mathrm{SD})$ in the Four Well Nests $(n=6)$ and $t$ Values and Significant Levels (Paired $t$ Test) ${ }^{\mathrm{a}}$

\begin{tabular}{|c|c|c|c|c|c|c|c|c|c|}
\hline \multirow[b]{2}{*}{$\mathrm{Cl}, \mathrm{mg} \mathrm{L}^{-1}$} & \multirow[b]{2}{*}{ Mean \pm SD } & \multicolumn{2}{|c|}{ Row 1} & \multicolumn{2}{|c|}{ Row 2} & \multicolumn{2}{|c|}{ Row 3} & \multicolumn{2}{|c|}{ Row 4} \\
\hline & & $t$ & df & $t$ & df & $t$ & df & $t$ & $\mathrm{df}$ \\
\hline Stream & $30 \pm 14$ & 3.47 & $-22^{b}$ & -1.3 & 28 n.s. & 0.3 & 28 n.s. & 1.3 & 28 n.s \\
\hline Row 1 & $33.1 \pm 12$ & & & 0.1 & 25 n.s. & 3.4 & $26^{\mathrm{b}}$ & 4 & $25^{\mathrm{c}}$ \\
\hline Row 2 & $32.1 \pm 12$ & & & & & 4 & $32^{c}$ & 6 & $28^{\mathrm{c}}$ \\
\hline Row 3 & $25.1 \pm 9$ & & & & & & & 0.7 & $35 \mathrm{n} . \mathrm{s}$ \\
\hline Row 4 & $25 \pm 8$ & & & & & & & & \\
\hline \multicolumn{10}{|l|}{$\mathrm{N}-\mathrm{NO}_{3}, \mathrm{mg} \mathrm{L}^{-1}$} \\
\hline Stream & $0.28 \pm 0.5$ & 2 & 35 n.s. & 3.7 & $41^{\mathrm{c}}$ & 6.2 & $42^{c}$ & 9.8 & $42^{\mathrm{c}}$ \\
\hline Row 1 & $0.37 \pm 0.5$ & & & 2.1 & 37 n.s. & 3.9 & $42^{c}$ & 8.4 & $42^{\mathrm{c}}$ \\
\hline Row 2 & $0.67 \pm 0.6$ & & & & & 0.4 & 49 n.s. & 9.6 & $50^{\mathrm{c}}$ \\
\hline Row 3 & $0.89 \pm 0.4$ & & & & & & & 8.9 & $51^{\mathrm{c}}$ \\
\hline Row 4 & $3.2 \pm 4.2$ & & & & & & & & \\
\hline \multicolumn{10}{|l|}{$\mathrm{DOC}, \mathrm{mg} \mathrm{L}^{-1}$} \\
\hline Stream & $5.7 \pm 1.8$ & 2.7 & 10 n.s. & 8.2 & $10^{\mathrm{c}}$ & 8.1 & $10^{\mathrm{c}}$ & 8.8 & $10^{\mathrm{c}}$ \\
\hline Row 1 & $3.4 \pm 2.9$ & & & 4.2 & $17^{\mathrm{c}}$ & 3.9 & $17^{\mathrm{c}}$ & 4.6 & $17^{\mathrm{c}}$ \\
\hline Row 2 & $1.6 \pm 0.9$ & & & & & 1.5 & 17 n.s. & 5.6 & $17^{\mathrm{c}}$ \\
\hline Row 3 & $1.4 \pm 0.95$ & & & & & & & 4.0 & $17^{\mathrm{c}}$ \\
\hline Row 4 & $1.1 \pm 0.7$ & & & & & & & & \\
\hline
\end{tabular}

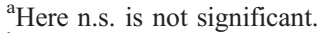

${ }^{\mathrm{b}} \mathrm{P}<0.01$.

${ }^{\mathrm{c}} \mathrm{P}<0.001$.

[40] Oxygen concentrations averaged: $4.1 \pm 1 \mathrm{mg} \mathrm{L}^{-1}$ in row $4 ; 3.6 \pm 1.1 \mathrm{mg} \mathrm{L}^{-1}$ in row $3 ; 4.1 \pm 2 \mathrm{mg} \mathrm{L}^{-1}$ in row 2 ; and $4.4 \pm 2 \mathrm{mg} \mathrm{L}^{-1}$ in row 1 . Differences between rows were not significant (Anova, $\mathrm{F}=0.4$, d.f. $=47, \mathrm{P}>0.05$ ).

\section{Discussion}

\subsection{Temporal and Spatial Groundwater Dynamics}

[41] The described hydrological cycle of the riparian stream aquifer interface in Fuirosos demonstrates that this boundary system is highly dynamic. The chloride data allowed us to identify two water bodies: the hillslope groundwater and the infiltrated stream water. On the other hand the hydrometic data set (i.e., groundwater levels and hydraulic gradients) enabled to (1) distinguish three periods within the hydrologic year; (2) to identify the location of the mixing between these two groundwater bodies; (3) to evaluate the relative importance of the hillslope groundwater and the stream water within the riparian area.

[42] Several studies suggest that the hyporheic zone may be linked to a dynamic stream aquifer interface system [Bencala, 1984]. Field results report a decline of water contribution from the stream to the total hyporheic groundwater at high discharges [Wroblichk et al., 1998; Wondzell and Swanson, 1996; Harvey et al., 1996]. This results from high groundwater levels limiting the discharge of the aquifer from the stream water [Harvey and Wagner, 2000]. In contrast, the pattern observed in the Fuirosos riparian zone was similar to that observed during occasional storms in ephemeral streams located in arid regions [Moench and Kisiel, 1970; Abdulrazzak and Morel-Seytoux, 1983]. This study shows that the spatial variability of hydraulic properties (expressed as hydraulic conductivity) of the soil-weathered rock system is essential to explain stream aquifer hydrological interactions. In Fuirosos, the high hydraulic conductivity in the stream edge zone favored the rapid stream water infiltration in the surrounding riparian area regulating the stream runoff generation during the dry and the stream discharge periods [Butturini et al., 2002]. On the other hand, low hydraulic conductivity in deep saturated hillslope sediments limits the hillslope groundwater flux.

\subsection{Groundwater Nitrate Dynamics}

[43] Results here show an important spatial heterogeneity of the nitrate removal spatial rate within the riparian groundwater compartment of Fuirosos. An effective nitrate

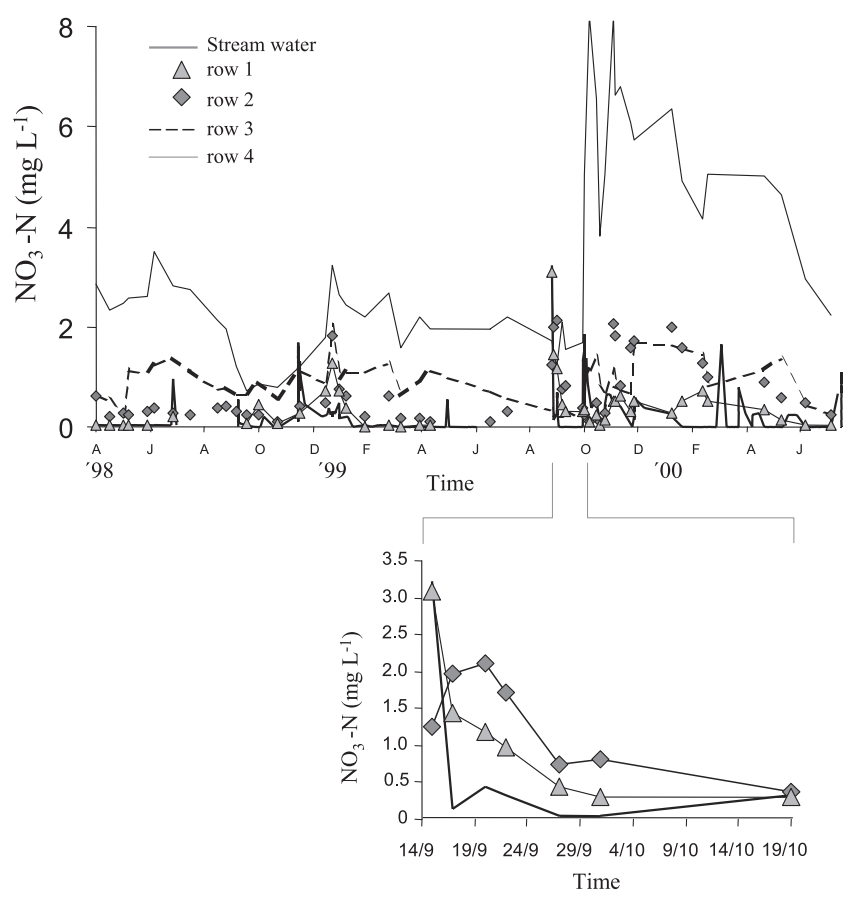

Figure 10. Changes in $\mathrm{NO}_{3}-\mathrm{N}$ concentration in stream water and riparian groundwater during the study period. The bottom graph shows a detail of nitrate dynamics in the stream water and in the stream edge zone groundwater (i.e., rows 1 and 2) during the stream discharge period in 1999. 

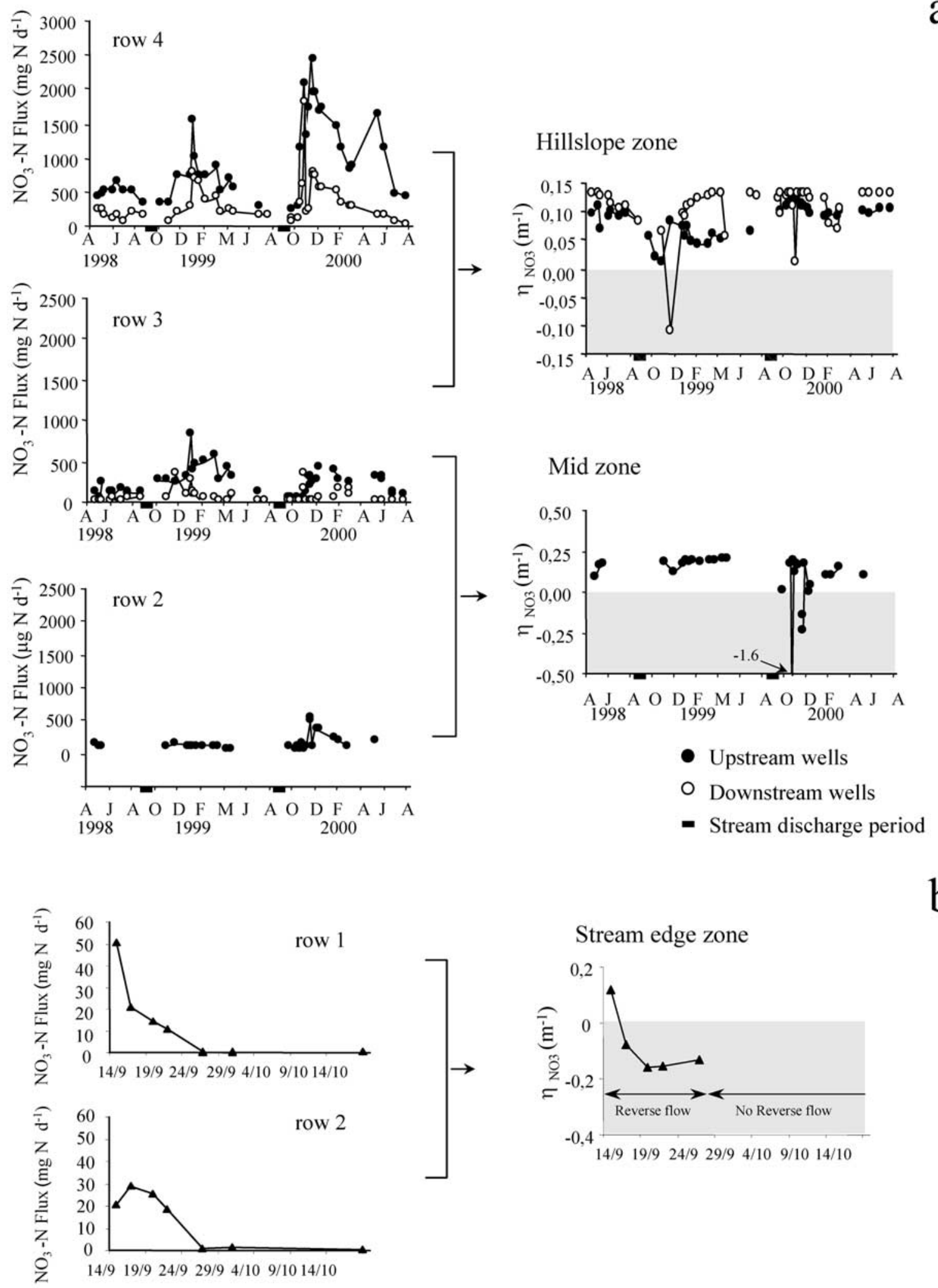

b

Figure 11. Changes in $\mathrm{NO}_{3}-\mathrm{N}$ groundwater fluxes (a) in the hillslope and midzones during the hillslope recharge and dry periods and (b) in the near-stream zone during the stream recharge period and associated nitrate removal spatial rates $\left(\eta_{\mathrm{NO} 3}, \mathrm{~m}^{-1}\right)$. Shaded area indicates nitrate release $\left(\eta_{\mathrm{NO} 3}<0\right)$. 
removal was measured in the deep groundwater of the hillslope zone near the agricultural field meanwhile the nitrate release predominated in riparian groundwater adjacent to the stream channel (Figure 11). The nitrate removal capacity appeared to be related to the hydraulic properties of the soil-weathered bedrock system. The low water fluxes in the hillslope zone favored high groundwater residence times and enhanced the nitrate removal. Whereas, highly conductivity sediments in the stream edge zone were associated with nitrate flushing. The role of sediment hydraulic properties in nitrate removal is still contradictory and literature data are mostly related to saturated riparian systems. Devito et al. [2000], Hill [1990], and Brusch and Nilsson [1993] estimated low nitrate removal in highly conductive sediments, while Haycock and Burt [1993a] measure high nitrate removal. In Fuirosos, the short autumnal stream discharge period is a key event to understand the riparian nitrogen biogeochemistry. In few hours, stream water infiltrated rapidly into the surrounding riparian zone with the formation of a rising groundwater table into the unsaturated upper soil layer adjacent to the stream channel. This fact favored the rapid mobilization of soluble nitrate stored in the upper unsaturated riparian soil layer during the dry period with consequent increase of nitrate concentration in groundwater. Similar mechanisms explained the temporal dynamics of nitrate and dissolved organic carbon in streams draining temperate [Creed et al., 1996] and alpine catchments [Hornberger et al., 1994]. In Fuirosos, the unsaturated riparian organic soil layer is a source of nitrate. During the dry period, nitrification rates in the upper soil layer averaged $2 \mathrm{mg} \mathrm{N} \mathrm{kg}$ soil $\mathrm{d}^{-1}$ and nitrate concentrations between 14 and $115 \mathrm{~N}^{-N_{3}} \mathrm{mg} \mathrm{L}^{-1}$ were observed in soil leachates during rain storms [Bernal et al., 2003].

[44] Most research effort has been focused on organicrich and saturated riparian soils in anoxic conditions. Denitrification has been the most studied mechanism for nitrate removal [Cirmo, 1997; Hill, 2000]. However, in the riparian zone of Fuirosos, the organic soil layer and the groundwater were not linked, suggesting that the ideal environmental conditions for denitrification are uncommon in unsaturated soils such as our study site. Denitrification in groundwater is a well studied process, nevertheless it is difficult to get field estimations in deep aquifers [Korom, 1992]. Several studies provided evidences that this mechanism can be an important factor in nitrate depletion in shallow unconfined aquifers [Gillham and Cherry, 1978; Trudell et al., 1986; McMahon and Bohlke, 1996]. Denitrification at several meters depth of a riparian floodplain has been associated with high supplies of DOC in narrow hot spots [Hill, 2000]. However, DOC concentrations lower than $4-5 \mathrm{mg} \mathrm{L}^{-1}$, such as those in Fuirosos, seem to be insufficient to sustain denitrification [Starr and Gillham, 1993; Devito et al., 2000]. Low DOC in deep groundwater in the riparian hillslope zone, coupled with relatively high $\mathrm{O}_{2}$ concentrations $\left(3.5-4 \mathrm{mg} \mathrm{L}^{-1}\right)$ suggest that the heteretrophic denitrification would is negligible in our riparian site.

[45] Plant uptake has also been recognized as a potential mechanism for nitrate depletion in riparian systems [Fail et al., 1986]. However, it is difficult to determine the relation between plant nitrogen uptake and the nitrate removal [Komor and Magner, 1996; Pinay et al., 1998]. The uptake by riparian forest may account for a minor portion of nitrate removal [Jacobs and Gilliam, 1983; Peterjohn and Correl, 1984]. The lack of a seasonal pattern in nitrate removal spatial rate $\left(\eta_{\mathrm{NO} 3}\right)$ in the hillslope zone of Fuirosos riparian strip suggests that London plane tree trees do not seem to play an important role in groundwater nitrate depletion. The tree activity peaks in spring and summer [Nin, 2000] when groundwater level was located at 1.5-2.5 m depth. Conversely, in autumn and winter, when the forest is dormant and the groundwater level was located $1 \mathrm{~m}$ below ground surface, the nitrate removal in deep groundwater was still operative. Therefore it seems to be an apparent discordance between the tree activity and nitrate depletion in groundwater.

[46] Field data could not identify the precise mechanism of nitrate depletion in the deep groundwater flowing through the hillslope riparian zone. However, these results suggest that there are other processes, than denitrification, accounting for measured groundwater nitrate removal. One possible mechanism is microbial assimilation [Korom, 1992].

\section{Conclusion}

[47] The riparian zone of Fuirosos is characterized by a dynamic stream aquifer interface. The riparian groundwater levels were subjected to dramatic seasonal changes along the hydrological year. Stream water discharged down to 10 $m$ into the riparian zone during the short transition between the dry and the hillslope groundwater recharge periods. The stream discharge caused a rising groundwater table into the unsaturated riparian soil layer adjacent to the stream channel, which results in the rapid flushing of nitrate stored in soil during the long dry period. Therefore nitrate release predominated in the stream edge zone of the riparian strip. On the other hand, nitrate was efficiently removed from the deep groundwater flowing into the hillslope riparian zone through sediments with low hydraulic conductivity. This opposite pattern of nitrate removal observed in such small area suggests that the depletion of nitrate in groundwater through riparian systems bounded by intermittent streams require careful consideration.

[48] Acknowledgments. We thank Antoni Bombí (Diputació de Barcelona, Servei Parcs Naturals) and Joan Cerrato-Gallego for their support in the field, David Balaya for comments on English typescript and Joan Lluis Riera for providing the map of the study catchment. We thank the stimulating contributions of F. Gallard and T. Battin. This study was supported by funds provided by the European Community (NICOLAS project, ENV4CT97-0395 and INCA project EVK1-1999-00011) and the Comisión Interministerial de Ciencia y Tecnología (CICYT, REN2001-3327).

\section{References}

Abdulrazzak, M. J., and H. J. Morel-Seytoux, Recharge from an ephemeral stream following wetting front arrival to water table, Water Resour. Res., 19, 194-200, 1983.

Altman, S. J., and R. M. Parizek, Dilution of nonpoint-source nitrate in groundwater, J. Environ. Qual., 24, 707-718, 1995.

Batu, V., Aquifer Hydraulics: A comprehensive Guide to Hydrogeologic Data Analysis, John Wiley, New York, 1998.

Bencala, K. E., Interactions of solutes and streambed sediment: 2. A dynamic analysis of coupled hydrologic and chemical processes, Water Resour. Res., 20, 1804-1814, 1984.

Bencala, K. E., A perspective on stream-catchment connections, J. N. Am. Benthol. Soc., 12, 44-47, 1993. 
Bernal, S., A. Butturini, E. Nin, F. Sabater, and S. Sabater, Leaf litter dynamics and nitrous oxide emission in a Mediterranean riparian forest, J. Environ. Qual., 32, 191-197, 2003.

Brusch, W., and B. Nilsson, Nitrate transformation and water movement in a wetland area, Hydrobiologia, 251, 103-111, 1993.

Butturini, A., and F. Sabater, Ammonium and phosphate retention in a Mediterranean stream: Hydrological versus temperature control, Can. J. Fish. Aquat. Sci., 55, 1-8, 1998.

Butturini, A., S. Bernal, S. Sabater, and F. Sabater, The influence of the riparian-hyporheic zone on the hydrological responses in an intermittent stream, Hydrol. Earth Syst. Sci., 6, 515-526, 2002.

Cirmo, C. P., and J. J. McDonnell, Linking the hydrologic and biogeochemical controls of nitrogen transport in near-stream zones of temperateforested catchments: A review, J. Hydrol., 199, 88-120, 1997.

Correl, D. L., Buffer zones and water quality protection: General principles, in Buffer Zones: Their Processes and Potential in Water Protection, edited by N. E. Haycock et al., pp. 7-20, Quest Environ., Hertfordhire, UK, 1997.

Creed, I. F., L. E. Band, N. W. Foster, I. K. Morrison, J. A. Nicolson, R. S. Semkin, and D. S. Jeffries, Regulation of nitrate-N release from temperate forests: A test of the $\mathrm{N}$ flushing hypotheis, Water Resour. Res., 32, 3337-3354, 1996.

Devito, K. J., D. Fitzerald, A. R. Hill, and R. Aravena, Nitrate dynamics in relation to lithology and hydrologic flow path in a river riparian zone, J. Environ. Qual., 29, 1075-1084, 2000.

Fail, J. L., M. N. Hamzah, B. L. Haines, and R. L. Todd, Above and below ground biomass, production, and element accumulation in riparian forests of an agricultural watershed, in Watershed Research Perspectives, edited by D. L. Correl, pp. 193-224, Smithsonian Press, Washington, D.C., 1986

Freeze, R. A., and J. A. Cherry, Groundwater, 604 pp., Prentice-Hall, Old Tappan, N.J., 1979

Gillham, R. W., and J. A. Cherry, Field evidence of denitrification in shallow groundwater flow systems, Water. Pollut. Res. Can., 13, 5371,1978 .

Gilliam, J. W., Riparian wetlands and water quality, J. Environ. Qual., 28, 896-900, 1994

Guimerá, J., Anomalously high nitrate concentrations in groundwater, Ground Water, 36, 275-280, 1998.

Harvey, J. W., and B. J. Wagner, Quantifying hydrologic interactions between streams and their subsurface hyporheic zones, in Streams and Groundwater, edited by J. B. Correl and P. J. Mulholland, pp. 3-44, Academic, San Diego, Calif., 2000.

Harvey, J. W., B. J. Wagner, and K. E. Bencala, Evaluating the reliability of the stream tracer approach to characterize stream-subsurface water exchange, Water Resour. Res., 32, 2441-2451, 1996.

Haycock, N. E., and T. P. Burt, Role of floodplain sediments in reducing the nitrate concentrations of subsurface run-off: A case study in the Cotswolds, UK, Hydrol. Processes, 7, 287-295, 1993a.

Haycock, N. E., and T. P. Burt, The sensitivity of rivers to nitrate leaching: The effectiveness of near-stream land as a nutrient retention zone, in Landscape Sensitivity, edited by R. J. Allison and D. S. G. Thomas, pp. 161-272, John Wiley, New York, 1993b.

Hill, A. R., Groundwater flow paths in relation to nitrogen chemistry in the near-stream zone, Hydrobiologia, 206, 39-52, 1990.

Hill, A. R., Nitrate removal in stream riparian zones, J. Environ. Qual., 25, $743-755,1996$

Hill, A. R., Stream chemistry and riparian zones, in Streams and Groundwater, edited by J. B. Jones and P. J. Mulholland, pp. 83-110, Academic, San Diego, Calif., 2000

Hornberger, G. M., K. E. Bencala, and D. M. McKnight, Hydrological controls on dissolved organic carbon during snowmelt in the Snake River near Montezuma, Colorado, Biogeochemistry, 25, 147-165, 1994.

Jacobs, C. R., and J. W. Gilliam, Nitrate loss from agricultural drainage waters: Implications for non-point source control, Univ. of N.C., Raleigh, 1983.

Jacobs, T. J., and J. W. Gilliam, Riparian losses of nitrate from agricultural drainage waters, J. Environ. Qual., 14, 472-478, 1985.

Komor, S. C., and J. A. Magner, Nitrate in groundwater and water sources used by riparian trees in agricultural watershed: A chemical and isotopic investigation in southern Minnesota, Water Resour. Res., 32, 1039-1050, 1996.
Korom, S. F., Natural denitrification in saturated zone: A review, Water Resour. Res., 32, 1657-1668, 1992.

Martí, E., S. G. Fisher, J. D. Schade, and N. B. Grimm, Flood frequency and stream-riparian linkages in arid streams, in Streams and Groundwater, edited by J. B. Jones and P. J. Mulholland, pp. 111-136, Academic, San Diego, Calif., 2000.

McMahon, P. B., and J. K. Bohlke, Denitrification and mixing in a streamaquifer system: Effects on nitrate loading to surface water, J. Hydrol., 186, 105-128, 1996.

Meyer, J. L., Stream health: Incorporating the human dimension to advance stream ecology, J. N. Am. Benthol. Soc., 16, 439-447, 1997.

Moench, A. F., and C. C. Kisiel, Application of the convolution relation to estimating recharge from an ephemeral stream, Water Resour. Res., 6, 1087-1094, 1970

Newman, B. D., A. R. Campbell, and B. P. Wilcox, Lateral subsurface flow pathways in a semiarid ponderosa pine hillslope, Water Resour. Res., 34, 3485-3496, 1998

Nin, E., Paper del bosc de ribera en la retenció del nitrogen, Master experimental en Biología, Univ. de Barcelona, Barcelona, Spain, 2000.

Peterjohn, W. T., and D. L. Correl, Nutrient dynamics in an agricultural watershed: Observations on the role of a riparian forest, Ecology, 65, $1466-1475,1984$.

Pinay, G., C. Ruffinoni, S. Wondzell, and F. Gazell, Change in groundwater nitrate concentration in a large river floodplain: Denitrification, uptake, or mixing?, J. N. Am. Benthol. Soc., 17, 179-189, 1998.

Reynols, J. M., An Introduction to Applied and Environmental Geophysics 796 pp., John Wiley, New York, 1997.

Romano, J., and J. Krol, Capillary ion electrophoresis, an environmental method for the determination of anions in waters, J. Chromatogr., 640, 403-412, 1993

Sabater, S., A. Butturini, S. Bernal, E. Nin, and F. Sabater, Wood and leaf debris input in a Mediterranean stream: The influence of riparian vegetation, Verh. Int. Ver. Limnol., 153, 91-102, 2002.

Sabater, S., A. Butturini, J. C. Clement, D. Dowrick, M. Hefting, V. Maître, G. Pinay, C. Postolache, M. Rzepecki, and F. Sabater, Nitrogen removal by riparian buffers under various $\mathrm{N}$ loads along a European climatic gradient: patterns and factors of variation, Ecosystems, 6, 20-30, 2003.

Serrano, S. E., and S. R. Workmann, Modelling transient stream/aquifer interaction with non-linear Boussinesq equation and its analytical solution, J. Hydrol., 206, 245-255, 1998.

Standford, J. A., Rivers in the landscape: Introduction to the special issue on riparian and groundwater ecology, Freshwater Biol., 40, 402-406, 1998.

Starr, R. C., and R. W. Gillham, Denitrification and organic carbon availability in two aquifers, Ground Water, 31, 934-946, 1993.

Triska, F. J., V. C. Kennedy, R. J. Avanzino, G. W. Zellweyer, and K. E. Bencala, Retention and transport of nutrients in a third order stream in nothwestern California: Hyporheic processes, Ecology, 70, 1893-1905, 1989.

Trudell, J. M., R. W. Gillham, and J. A. Cherry, An in-situ study of the occurrence and rate of denitrification in a shallow unconfined sand aquifer, J. Hydrol., 83, 251-268, 1986.

Wolfram, S., Mathemathica: A System for Doing Mathemathics by Computer, Addison-Wesley-Longman, Reading, Mass., 1991.

Wondzell, S. M., and F. J. Swanson, Seasonal and storm dynamics of the hyporheic zone of a 4th-order mountain steam. I: Hydrological processes, J. N. Am. Benthol. Soc., 15, 3-19, 1996.

Wroblichk, G. J., M. E. Campana, H. M. Valett, and C. N. Dahm, Seasonal variation in surface-subsurface water exchange and lateral hyporheic area of two stream-aquifer systems, Water Resour. Res., 34, 317-328, 1998.

S. Bernal, E. Nin, and F. Sabater, Departament de Ecología, Universitat de Barcelona, Avd. Diagonal 645, 08028 Barcelona, Spain.

A. Butturini, Institute of Earth Sciences Jaume Almera (CSIC), Lluis Sole Sabaris s/n, 08028 Barcelona, Spain. (abutturini@ija.csic.es)

C. Hellin and L. Rivero, Departament de Geoquímica Petrologia I Prospecció Geológica, Zona Universitaria de Pedralbes, 08071 Barcelona, Spain.

S. Sabater, Departament Ecología Aquática, Universitat de Girona, Campus Montilivi, Girona, Spain. 